\title{
ISOLASI DAN KARAKTERISASI EKSTRAK ETANOL DAUN LEILEM \\ (Clerodendrum minahassae Teijsm dan Binn.) DENGAN METODE SPEKTROFOTOMETRI \\ ISOLATION AND CHARACTERIZATION ETHANOL EXTRACT OF LEILEM \\ LEAVES (Clerodendrum minahassae Teijsm and Binn) WITH METHODS SPECTROPHOTOMETRIC
}

\author{
Yuri Pratiwi Utami ${ }^{1)}$, Imrawati ${ }^{1)}$, Abd.Rasyid.D ${ }^{1)}$ \\ ${ }^{1)}$ Program studi sarjana farmasi, Sekolah Tinggi Ilmu Farmasi Makassar \\ Jl. Perintis Kemerdekaan KM.13,7 Daya telp/fax. 0411-583190 Makassar 90242 \\ yuri_pratiwi@yahoo.co.id
}

\begin{abstract}
Leilem leaf (Clerodendrum minahassae Teijsm .And Binn.) have been reported in traditional medicine for the treatment of various deseases such as stomatch ache and ascariasis. In Minahassa, leilem leaf generally consumed as vegetables. The present study revealed that leilem leaf can inhibit the growth of escherhia coli because of the presence of flavonoid that can demage bacterial cell membranes. This study at characterization of isolated compounds from ethanol extract of leilem leaves (Clerodendrum minahassae Teijsm and Binn). Extraction was done maceration using 70\% ethanol with the percentage of rendement was 10,19\%. The phytochemical analysis of ethanol extract of leilem leaves showed a positive result of alkoloid, flavonoid, streroid and tanin. The ethyl acetate extract was selected and 2 grams of it was taken to continued to second conventional column chromatography and 5 fractions were obtained. Fraction 2 was choosen and continued to preparative and result 2 isolates. Isolate 2 that showed one spot on tlc with $\mathrm{rf}$ 0,66. Was continued for spectrofotometri $u v$-vis and ftir analysis. The spectrophotometer $u v$-vis maximum wavalength at $269,0 \mathrm{~nm}$ and 333, $0 \mathrm{~nm}$. The ftir data indicated the presence of functional $\mathrm{O}-\mathrm{H}, \mathrm{C}-\mathrm{H}, \mathrm{C}=\mathrm{C}$ and $\mathrm{C}-\mathrm{O}$ which is suspected ad flavonoid.
\end{abstract}

Keywords : Isolation, Characterization, leilem leaf (Clerodendrum minahassae Teijsm and Binn)

\begin{abstract}
ABSTRAK
Daun leilem (Clerodendrum minahassae Teijsm dan Binn.) dilaporkan yaitu sebagai obat tradisional untuk menyembuhkan beberapa penyakit, seperti sakit perut dan Ascariasis. Daun leilem biasanya dikonsumsi sebagai sayuran oleh masyarakat di Minahasa. Penelitian ini bertujuan untuk mengetahui profil (karakter) senyawa yang diisolasi dari ekstrak etanol daun leilem (Clerodendrum minahassae Teijsm dan Binn.) ekstrak diperoleh dari proses maserasi menggunakan pelarut etanol $70 \%$ dengan persen rendamen 10,19\%. Hasil uji kandungan kimia ekstrak etanol daun leilem positif mengandung alkaloid, flavonoid, steroid dan tanin. Ekstrak etil astetat dipilih dan diambil 2 gram dilanjutkan untuk dilakukan pemisahan menggunakan komatografi kolom konvensional dan menghasilkan 5 fraksi. Fraksi 3 dipilih dilanjutkan kromatografi kolom konvensional kedua dan didapatkan 5 fraksi. Fraksi 2 dipilih dan dilanjutkan ketahapan kromatgrafi lapis tipis preparatif dan menghasilkan 2 isolat. Isolat 2 yang menunjukkan 1 noda tunggal pada profil KLT dengan niliai Rf 0,66 dilanjutkan untuk dianalisis dengan spektofometri UV-Vis dan FT-IR. Hasil analisis spektrofotometri UV-Vis isolat 2 mempunyai serapan maksimal pada panjang gelombang $269,0 \mathrm{~nm}$ dan $333,0 \mathrm{~nm}^{-1}$. Data FT-IR menunjukkan adanya gugus fungsi $\mathrm{O}-\mathrm{H}, \mathrm{C}-\mathrm{H}, \mathrm{C}=\mathrm{C}$ dan $\mathrm{C}-\mathrm{O}$ yang diduga merupakan senyawa flavonoid.
\end{abstract}


Kata kunci: Isolasi, karakteriksasi, Daun Leilem(Clerodendrum minahassae Teijsm and Binn).

1

PENDAHULUAN

Yuri pratiwi utami dkk... 
Salah satu negara yang memiliki keanekaragaman obat di dunia yaitu Indonesia. Wilayah hutan tropika Indonesia memiliki keanekaragaman hayati tertinggi ke2 di dunia setelah Brazili. Sebanyak 40.000 jenis flora yang ada di dunia, terdapat 30.000 jenis dapat dijumpai di Indonesia dan 940 jenis diantaranya diketahui berkhasiat sebagai obat dan telah dipergunakan dalam pengobatan tradisional secara turun-temurun oleh berbagai etnis di Indonesia. Jumlah tumbuhan obat tersebut sekitar $90 \%$ dari jumlah tumbuhan obat yang terdapat dikawasan Asia (Masyhud,2010). Keanekaragaman hayati ini termasuk dalam sumber daya alam yang menghasilkan senyawa kimia yang tidak terbatas jenis dan jumlahnya. Khususnya di daerah Minahassae, jenis tanaman yang banyak tumbuh dan dimanfaatkan sebagi sumber makanan yaitu tanaman leilem (Clerodendrum minahassae L.). Tanaman leilem ini termasuk dalam genus Clerodendrum dan famili Verbeneceae (Wiart ,2002).

Leilem (Clerodendrum minahassae Teijsm. Dan Binn) merupakan satu spesies dari genus Clerodendrum. Genus Clerodendrum banyak tersebar diseluruh dunia dan memliliki lebih dari 500 spesies. Banyak dari genus ini digunakan sebagai obat tradisional dan sebagai pengobatan secara turun temurun untuk mengobati berbagai macam penyakit (Patel dan Shrivastava, 2007).

Menurut Patel dan Shrivastava, 2007 Bagian tanaman leilem ini Yuri pratiwi utami dkk... yaitu daun, biasanya dikonsumsi sebagai sayuran oleh masyarakat di Minahasa. Manfaat lain dari daun leilem ini yaitu sebagai obat tradisional untuk menyembuhkan beberapa penyakit, seperti sakit perut dan Ascariasis

Berdasarkan pendekatan etnofarmakologi diketahui bahwa genus Clerodendrum memiliki berbagai peranan penting dalam perkembangan pengobatan diantaranya sebagai antiinflamasi, antidiabetes dan antibakteri (Patel \& Shrivastava, 2007). Senyawa fenol yang ada pada daun leilem merupakan jenis polifenol dengan aktivitas antioksidan yang berpotensi sebagai terminator radikal bebas (Emor, 2006) Adam dkk. (2013) melaporkan bahwaekstrak metanol daun leilem memiliki aktivitas antioksidan berkisar antara 64,83 70,12\%. Bontjuradkk., meneliti bahwa senyawa fenol dalam ekstrak daun leilem memiliki efek antibakteri terhadap bakteri Streptococcus mutans. Penelitian lain melaporkan bahwa daun leilem dapat menghambat pertumbuhan bakteri Escherichia coli karena flavonoid yang terdapat didalamnya dapat merusak membran sel bakteri (Lomboan, 2015). Berdasarkan latar belakang diatas peneliti tertarik melakukan peneilitian tentang isolasi dan karakterisasi ekstrak daun leilem (Clerodendrum minahassae Teijsm. \& Binn.).

\section{METODE PENELITIAN} Jenis Penelitian 
Jenis penelitian ini adalah penelitian eksperimen berskala laboratorium.

\section{Waktu dan Tempat Penelitian}

Penelitian ini dilaksanakan di Laboratorium Biologi Farmasi Sekolah Tinggi Ilmu Farmasi Makassar, Laboratorium Kimia Terpadu Fakultas MIPA Universitas Hasanudin dan Laboratorium Kimia Farmasi Universitas Hasanudin pada bulan November 2017 sampai Januari 2018.

\section{Prosedur Penelitian \\ Pengambilan Sampel}

etanol $70 \%$ sebanyak 3 Liter padatemperatur ruangan dan terlindung dari cahaya selama 5 hari sambil sesekali diaduk. Kemudian disaring residu dan filtrat dipisahkan, selanjutnya diremaserasi ampasnya dengan perlakuan yang sama, filtrat yang diperoleh dikumpulkan dengan filtrat 1 kemudian diuapkan di evaporator hingga diperoleh ekstrak kental daun leilem (Clerodendrum minahassae Teijsm. \& Binn.).

\section{Uji Kandungan Kimia}

Uji kandungan kimia meliputi : Uji Alkaloid, Uji Flavonoid, Uji Tanin, Uji Terpenoid dan Steroid, Uji Saponin.

\section{Proses Pemisahan}

\section{Partisi / Fraksinasi}

Fraksinasi ekstrak etanol daun leilem dengan menggunakan corong pisah. Ekstrak etanol daun leilem masingmasing sebanyak $5 \mathrm{~g}$ disuspensikan dengan menggunakan pelarut air 100 $\mathrm{mL}$. kemudian ditambahkan pelarut n-heksan $100 \mathrm{~mL}$ dilakukan sebanyak 4 kali sampai pelarut berwarna jernih. Kemudian

Yuri pratiwi utami dkk...
Sampel daun leilem diperoleh dari Kelurahan Kairagi Dua, Kecamatan Mapanget, Kota Manado, Provinsi Sulawesi Utara.

\section{Penyiapan Sampel}

Sampel daun leilem yang telah dipanen terlebih dahulu kemudian disortasi basah,dicuci dengan air mengalir hingga bersih, dirajang dan dikeringkan dengan cara terkena sinar matahari langsung. Selanjutnya sampel siap diekstraksi.

\section{Pembuatan Ekstrak}

Daun leilem sebanyak 350 gram dimaserasi menggunakan pelarut ditambahkan pelarut etil asetat 100 $\mathrm{mL}$ sebanyak 5 kali sampai pelarut berwarna jernih. Proses fraksinasi dilakukan sebanyak 4 kali, hasil fraksi n-heksan, etil asetat dan fraksi air dikumpulkan kemudian diuapkan hingga diperoeh fraksi kental.

\section{Kromatografi Lapis Tipis}

Orientasi eluen dilakukan sebelum melakukan proses pemisahan secara KLT menggunakan perbandingan eluen n-heksan:etil asetat masingmasing (9:1) (8:2) (7:3) (6:4) dan (5:5). Kemudian dipilih 1 eluen yang menghasilkan nilai Rf dan penampakan noda yang baik yaitu perbandingan eluen (9:1). Penampakan terhadap noda dilakukan dengan menggunakan sinar UV 254 dan $366 \mathrm{~nm}$.

\section{Kromatografi Kolom}

Seperangkat alat kolom disiapkan, kemudian dimasukan sampel dan silika gel kedalam tabung kolom sebanyak 2 gram fraksi etil asetat dan 55 gram silika gel dengan 
menggunakan metode kemas basa (bubur siilika gel) sambil diketukketuk tabung kolom hingga mampat. Digunakan fase gerak berupa eluen yang bergradient dengan masingmasing perbandingan eluen (10:0), (9:1), (8:2), (7:3), (6:4), (5:5) (4:6) (3:7), (2:8), (1:9) dan (0:10), sesuai gradien dari tinggi ke rendah dibuat dalam $100 \mathrm{ml}$, dan ditambahkan metanol sebanyak $520 \mathrm{~mL}$.

Fraksi ditampung dalam botol vial masing-masing $10 \mathrm{ml}$ menghasilkan 131 fraksi, kemudian fraksi-fraksi tersebut digabungkan berdasarkan kesamaan warna sehingga diperoleh 9 fraksi, dengan melihat nilai Rf noda sehingga menghasilkan 5 fraksi,dipilih noda fraksi yang memenuhi kriteria dengan nilai 0,5 yaitu fraksi 3. Fraksi 3 sebanyak 335 mg dengan perbandingan silika gel 9,9 gram dipisakan kembali menggunakan kolom dengan metode kemas basa menggunakan eluen nheksan: etil asetat (9:1) sebanyak $1300 \mathrm{~mL}$ dan eluen metanol sebanyak $100 \mathrm{~mL}$.

Subfraksi ditampung dalam botol vial masing-masing $10 \mathrm{~mL}$ menghasilkan 144 fraksi, kemudian subfraksi digabungkan berdasarkan kesamaan warna sehingga diperoleh 13 subfraksi. Kemudian dikumpulkan 13 vial dipisahkan dengan metode KLT sehingga menghasilkan 5 subfraksi berdasarkan penampakan noda. Dipilih subfraksi 2 untuk dilanjutkan KLTP karena memiliki pola kromatogram yang ideal.

\section{Kromatografi lapis tipis preparatif}

Subfraksi 2 yang dipilih dilanjutkan pada kromatografi lapis tipis preparatif (KLTP) dengan menggunakan eluen n-heksan:etil asetat (9:1) dalam $100 \mathrm{~mL}$. Kemudian didapatkan 2 pita, dikerok dan dilarutkan dengan pelarut etil asetat p.a dan disaring dengan menggunakan pipet yang disumbat dengan kapas, filtrat yang diperoleh diuapkan. Dipilih pita 2 karena memiliki noda tunggal pada KLT.

\section{Karakterisasi Isolat}

Karakterisasi isolat murni dilakukan dengan menggunakan spektrofotometer UV-Vis dan spektrofotometer FT-IR.

\section{HASIL DAN PEMBAHASAN}

Sampel yang digunakan pada penelitian ini adalah ekstrak etanol daun leilem. Sampel diekstraksi menggunakan maserasi, maserasi merupakan salah satu metode pemisahan senyawa dengan cara perendaman pada temperatur ruangan dengan menggunakan pelarut organik. Maserasi dipilih karena merupakan metode secara dingin, dimana senyawa yang tidak tahan terhadap pemanasan tidak akan rusak dengan cara maserasi menggunakan cairan penyari etanol.

Pemilihan pelarut etanol dalam penelitian ini sebagai cairan penyari karena etanol mempunyai dua gugus fungsi yang berbeda kepolarannya, yaitu gugus hidroksi yang bersifat polar dan gugus alkil yang bersifat nonpolar. Adanya kedua gugus tersebut pada etanol diharapkan senyawa-senyawa dengan tingkat kepolaran yang berbeda akan 
terekstraksi dalam etanol (Harbone,

Ekstrak diperoleh dari hasil ekstraksi dengan menggunakan metode maserasi sebanyak 35,67 g dengan persen rendemen sebesar 10,19\%. Ekstrak kental yang diperoleh selanjutnya dilakukan uji
1987).

kandungan kimia. Uji kandungan kimia bertujuan untuk memberikan gambaran awal komposisi kandungan kimia (Depkes RI., 2000).

\section{Tabel 1. Uji Golongan Senyawa Kimia ekstrak etanol daun leilem}

\begin{tabular}{|c|c|c|c|}
\hline \multicolumn{2}{|c|}{$\begin{array}{c}\text { Kandungan Senyawa } \\
\text { Kimia }\end{array}$} & Hasil & Ket \\
\hline \multirow{3}{*}{ Alkaloid } & P.Mayer & Endapan putih & + \\
\hline & P.Wagner & Endapan cokelat & + \\
\hline & P.Dragendorf & Endapan jingga & + \\
\hline \multicolumn{2}{|c|}{ Steroid } & Berwarna hijau & + \\
\hline \multicolumn{2}{|c|}{ Terpenoid } & $\begin{array}{c}\text { Tidak terbentuk } \\
\text { warna cokelat antar } \\
\text { permukaan }\end{array}$ & - \\
\hline \multicolumn{2}{|c|}{ Flavonoid } & Berwarna jingga & + \\
\hline \multicolumn{2}{|c|}{ Saponin } & $\begin{array}{l}\text { Terbentuk buih yang } \\
\text { tidak mencanai } 1 \mathrm{~cm}\end{array}$ & - \\
\hline \multicolumn{2}{|c|}{ Tanin } & Berwarna cokelat & + \\
\hline
\end{tabular}

Berdasarkan hasil uji kandungan kimia menunjukkan bahwa daun leilem mengandung golongan senyawa alkaloid, steroid, flavonoid dan tanin. Ekstrak kental daun leilem sebanyak $20 \mathrm{~g}$ dipartisi dengan metode ektraksi cair-cair yang sebelumnya telah diuji kelarutannya menggunaka pelarut n-heksan, etil asetat dan air . Dari hasil ekstraksi cair-cair diperoleh berat fraksi sebagai berikut.

Tabel 2. Hasil ekstraksi cair-cair daun leilem.

\begin{tabular}{|c|c|c|c|}
\hline \multirow{2}{*}{$\begin{array}{c}\text { Ekstrak } \\
\text { etanol daun } \\
\text { leilem }\end{array}$} & \multicolumn{3}{|c|}{ Ekstrak hasil partisi cair-cair } \\
\cline { 2 - 4 } & Fraksi n-heksan & Fraksi etil asetat & Fraksi air \\
\hline 20 gram & 2,4 gram & 3,4 gram & 12,67 gram \\
\hline
\end{tabular}

Hasil fraksinasi berupa fraksi nheksan, etil asetat dan fraksi air diorientasi eluen yaitu (9:1) (8:2) (7:3) (6:40 dan (5:5). Fraksi yang penampakan noda yang terbaik yaitu fraksi etil asetat dengan perbandingan eluenn-heksan: etil asetat (9:1) dilanjutkan dengan kromatografi kolom. Selanjutnya fraksi etil asetat sebanyak $2 \mathrm{gr}$ di pisahkan dengan kromatografi kolom dengan fase diam silika gel GF60 dan dielusi berturut-turut menggunakan eluen bergradient

Yuri pratiwi utami dkk... 
yaitu n-heksan, etil asetat dan metanol. Fraksi-fraksi yang diperoleh dari tahapan kromatografi kolom dilakukan proses kromatografi lapis tipis kembali untuk mengabungkan fraksi-fraksi yang sama berdasarkan warna dan nilai Rf-nya.

Metode kromatografi kolom ini merupakan metode yang optimal untuk memisahkan komponen kimia yang jumlahnya sedikit dan hasilnya Hasil kromatografi kolom konvensional diperoleh 131 botol vial sebanyak 9 fraksi berdasarkan kesamaan warna larutan fraksi dan cepat diperoleh, dalam kromatografi kolom ini dipilih kromatografi kolom kovensional atau biasa disebut kromatografi gravitasi dibandingkan dengan kromatografi vacum walaupun membutuhkan waktu yang lebih lama dibandingkan dengan kromatografi vacum, akan tetapi hasil yang diperoleh lebih maksimal dibandingkan dengan menggunakkan kromatografi kolom vacum.

digabung berdasarkan kesamaan profil KLT diperoleh sebanyak 5 fraksi.

Tabel 3. Berat Fraksi Hasil Kromatografi Kolom Konvensional

\begin{tabular}{|c|c|}
\hline Fraksi & Berat $(\mathrm{mg})$ \\
\hline 1 & 6 \\
\hline 2 & 474 \\
\hline 3 & 335 \\
\hline 4 & 190 \\
\hline 5 & 866 \\
\hline
\end{tabular}

Fraksi 3 dipilih berdasarkan nilai Rf profil noda memiliki nilai $\mathrm{Rf}$ yang ideal. Fraksi 3 dengan berat $335 \mathrm{mg}$ dipilih untuk dilanjutkan pada Kromatografi kolom kedua agar didapat pemisahan senyawa yang lebih baik dan optimal dengan menggunakan eluen n-heksan : etil asetat (9:1) dalam $1300 \mathrm{~mL}$ dan metanol $100 \mathrm{~mL}$, sehingga diperoleh hasil kromatografi kolom kedua sebanyak 144 vial dan digabungkan berdasarkan warna menjadi 13 subfraksi dan digabungkan pada profil KLT sehingga diperoleh 5 subfraksi.

Tabel 4. Berat Fraksi 3 Hasil Kromatografi Kolom Konvensional kedua.

\begin{tabular}{|c|c|}
\hline Fraksi 3 & Berat (mg) \\
\hline 1 & 1,6 \\
\hline 2 & 10 \\
\hline 3 & 74 \\
\hline 4 & 24,3 \\
\hline 5 & 23,8 \\
\hline
\end{tabular}

Yuri pratiwi utami dkk... 
Subfraksi 2 dipilih berdasarkan nilai Rf profil noda memiliki nilai Rf yang ideal. Fraksi 2 dengan berat 10mg dipilih untuk dilajutkan pada KLT preparatif menggunakan fase gerak n-heksan : etil asetat (9:1) dan diamati menggunakan lampu UV $254 \mathrm{~nm}$ dan $366 \mathrm{~nm}$. Fraksi 2 menunjukkan penampakan noda KLT yang baik dibandingkan fraksi yang lain. Setelah diKLTP fraksi 2 menghasilkan 2 pita, pita 1 berwarna biru gelap dan pita 2 berwarna biru terang. kemudian pita-pita dikerok dan disentrifuse menggunakan pelarut etil asetat p.a, kemudian elusi kembali untuk dilihat penampakan noda. Metode KLT menunjukkan noda tunggal terdapat pada isolat pita 2 dengan nilai $\operatorname{Rf} 0,66$. Isolat pita 2 yang diperoleh selanjutnya dianalisis menggunakan intrumen UV-Vis dan FTIR. Hasil analisis isolat pita 2 dengan spektrofotometri $\mathrm{UV}-\mathrm{V}$ is memperlihatkan 2 puncak :

\section{Tabel 5. Hasil pembacaan spektrum UV-Vis Isolat 2}

\begin{tabular}{|c|c|c|c|}
\hline No & $\begin{array}{c}\text { Panjang } \\
\text { gelombang (nm) }\end{array}$ & Absorbansi & \multirow{2}{*}{ Perkiraan } \\
\hline 1 & 333 & 0,36762 & \multirow{2}{*}{ Flavonoid } \\
\hline 2 & 269 & 0,34551 & \\
\hline
\end{tabular}

Dari hasil spektrum UV-Vis senyawa Flavonoid (Markham, kemungkinan isolat mengandung 1988).

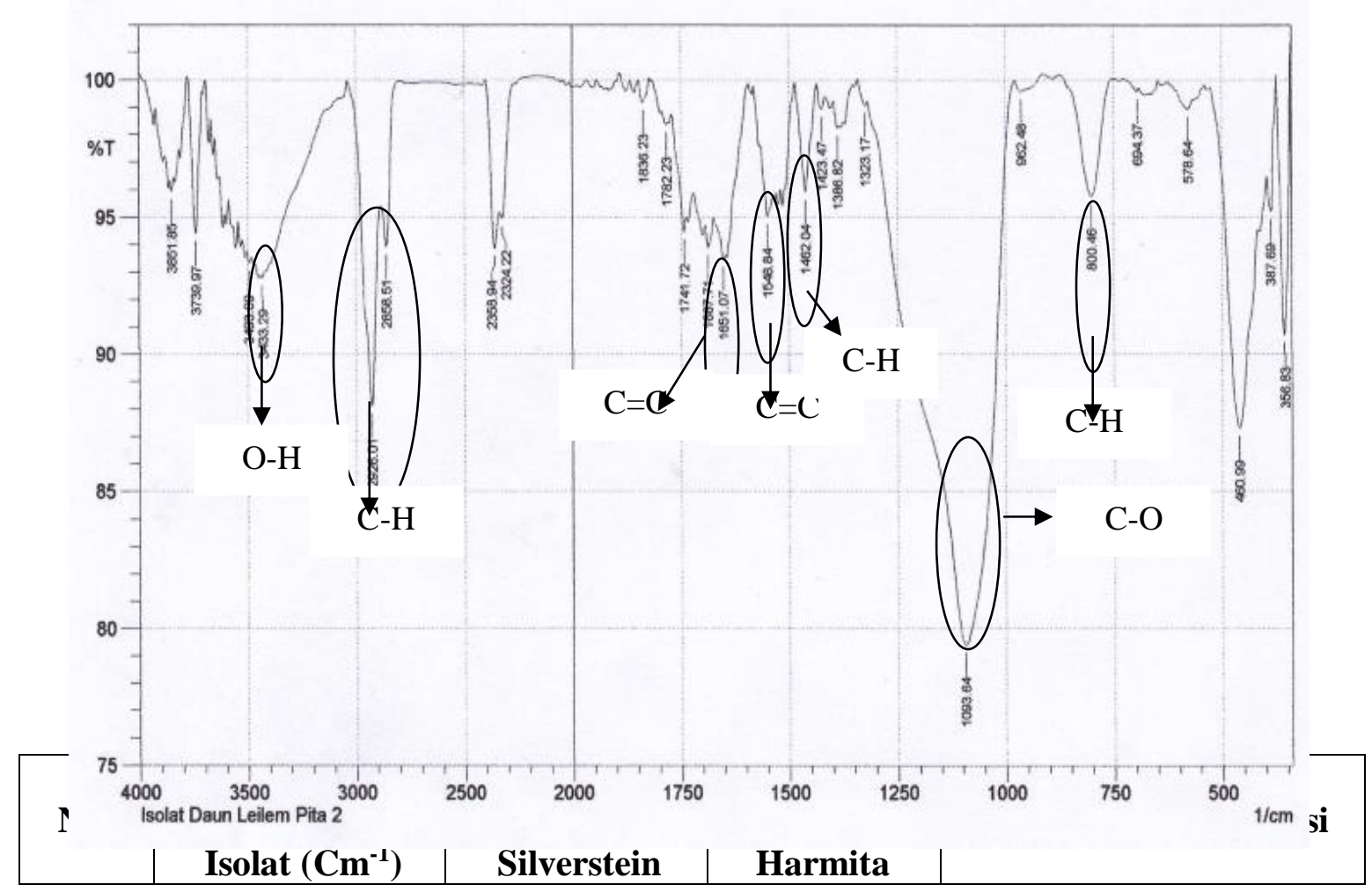

Yuri pratiwi utami dkk... 


\begin{tabular}{|c|c|c|c|c|}
\hline 1 & 800,46 & $675-870$ & & $\begin{array}{c}\text { C-H } \\
\text { (aromatik,Alkena) }\end{array}$ \\
\hline 2 & 1093,64 & $1080-1300$ & $1300-1000$ & $\begin{array}{c}\text { C-O } \\
\text { (Alkohol, } \\
\text { eter, asam karboksilat, } \\
\text { ester) }\end{array}$ \\
\hline 3 & 1462,04 & $1350-1470$ & - & $\begin{array}{c}\text { C-H } \\
\text { (Alkana) }\end{array}$ \\
\hline 4 & 1548,84 & $1500-1600$ & - & $\begin{array}{c}\text { C=C } \\
\text { (aromatik) }\end{array}$ \\
\hline 5 & 1651,07 & $1640-1680$ & $1680-1600$ & $\begin{array}{c}\text { C=C } \\
\text { (Alkena) }\end{array}$ \\
\hline 6 & 2858,51 & $2850-2960$ & $3000-2850$ & $\begin{array}{c}\text { C-H } \\
\text { (Alkana) }\end{array}$ \\
\hline 7 & 3433,29 & $3000-3600$ & $3500-3200$ & $\begin{array}{c}\text { O-H } \\
\text { (Alkohol) }\end{array}$ \\
\hline
\end{tabular}

Hasil analisis spektrofotometri Inframerah (IR) pada frekuensi serapan 3433,29 $\mathrm{cm}^{-1}$ diindikasikan sebagai gugus $\mathrm{O}-\mathrm{H}$ dengan intensitas kuat dimana gugus ini berada pada frekuensi $3000-3600 \mathrm{~cm}^{-1}$. Serapan pada frekuensi 2926,01 $2858,51 \mathrm{~cm}^{-1}$ diindikasikan sebagai gugus $\mathrm{C}-\mathrm{H}$ dengan intensitas kuat berada ada frekuensi 2850-2960 $\mathrm{cm}^{-1}$. Serapan pada frekuensi 1651,07 diindikasikan sebagai gugus $\mathrm{C}=\mathrm{C}$ dimana gugus ini berada pada frekuensi $\quad 1640-1680 \mathrm{~cm}^{-1}$ dengan intensitas sedang. Serapan pada frekuensi 1548,84 $\mathrm{cm}^{-1}$ diindikasikan sebagai gugus $\mathrm{C}=\mathrm{C}$ dimana gugus ini berada pada frekuensi 1500-1600 dengan intensitas kuat. Serapan pada frekuensi 1462,04 diindikasikan sebagai gugus $\mathrm{C}-\mathrm{H}$ yang berada pada frekuensi 1350-1470 dengan intesitas kuat. Serapan pada frekuensi 1093,64 diindikasikan sebagai gugus $\mathrm{C}-\mathrm{O}$ dimana gugus ini berada pada frekuensi 1080-1300 dengan intensitas sedang-kuat. Serapan pada frekuensi 800,46 diindikasikan sebagai gugus $\mathrm{C}-\mathrm{H}$ yang berada pada frekuensi 675-870 $\mathrm{cm}^{-1}$ dengan intensitas kuat (Silvertein, 2005) (Harmita, 2015).

Dari hasil analisis data spektrofotometri FT-IR diduga isolat pita 2 merupakan senyawa Flavonoid dengan gugus fungsi $\mathrm{O}-\mathrm{H}, \mathrm{C}-\mathrm{H}$, $\mathrm{C}=\mathrm{C}$, dan C-O. Keberadaan Flavonoid pada isolat pita 2 diduga karena adanya serapan pada frekuensi 3433,29 $\mathrm{cm}^{-1}$ yang diindikasikan sebagai gugus $\mathrm{O}-\mathrm{H}$, dan adanya gugus C-O pada frekuensi 1093,64 $\mathrm{cm}^{-1}$ dan didukung oleh data spektrofotometriUV-Vis dengan absorbansi maksimum pada panjang gelombang $333 \quad \mathrm{~nm}$ yang menunjukkan adanya Flavonoid (Markham, 1988).Untuk lebih memastikan senyawa apa yang

Yuri pratiwi utami dkk... 
terdapat dalam isolat pita 2 fraksi etil asetat daun leilem, maka harus dilakukan penelitian selanjutnya menggunakan alat spektrum lainnya seperti GC-MS dan NMR (Nucleic Magnetic Resonance).

\section{KESIMPULAN}

Berdasarkan hasil penelitian isolasi dan karakterisasi senyawa ekstrak etanol daun leilem isolat pita 2 yang diperoleh diduga merupakan

\section{DAFTAR PUSTAKA}

Adam, C., Djarkasi, G., Ludong, M. dan Langi, T., 2013, Penentuan Total Fenol dan Aktivitas Antioksidan Ekstrak Daun Leilem (Clerodendrum minahassae), PHARMACON JurnalIlmiah Farmasi, Manado, Indonesia, hal05.

Bontjura, S., Waworuntu, O. dan Siagian, K., 2015, Uji Efek Antibakteri Ekstrak Daun Leilem (Clerodendrum minahassae L.) Terhadap Bakteri Streptococcus mutans, PHARMACON Jurnalllmiah Farmasi, Manado, Indonesia, hal.99.

Departemen Kesehatan Republik Indonesia. 2000,Parameter standar umum ekstrak tumbuhan obat. Jakarta : Departemen Kesehatan.

Dirjen POM, 1986, Sediaan Galenik, Jilid II. Departemen Kesehatan RI. Jakarta. senyawa flavonoid yang didukung oleh uji golongan senyawa pada ekstrak yang menunjukkan hasil positif mengandung flavonoid, dan didukung oleh data spektrofotometri UV-Vis yang mempunyai absorbansi maksimal pada panjang gelombang 333,0 nm dan data Spektrofotometri FT-IR yang menunjukkan gugus fungsi $\mathrm{O}-\mathrm{H}, \mathrm{C}-\mathrm{H}, \mathrm{C}=\mathrm{C}$, dan $\mathrm{C}-\mathrm{O}$.

Emor, N., 2006,Isolasi dan Uji Aktivitas Antioksidan Ekstrak Daun Leilem (Clerodendrum minahassae L), Skripsi, Dr.,Universitas Samratulangi, Manado, Indonesia.

Fessenden, R.J., J.S Fessenden. 1997. Dasar-Dasar Kimia Organik. Diterjemahkan oleh Maun, S., Anas, A \& Sally, S. Jakarta: Binarupa Aksara

Harborne, J.B.,1987. Metode Fitokimia, Penuntun Cara Modern Menganalisis Tumbuhan, terbitan kedua,ITB. Bandung, Indonesia.

Harmita, 2015, Analisis Fitokimia Potensiometri dan Spektrokopi, Buku Kedokteran EGC : Jakarta.

Lomboan, L., 2015, Uji Efektivitas Ekstrak Metanol Daun Leilem (Clerodendrum minahassae, Teijsm, Binn.) terhadap Pertumbuhan Bakteri Escherichia coli, Politeknik 
Kesehatan Kementrian Kesehatan, Manado, Indonesia.

Masyhud, 2010. Tanaman Obat Indonesia. http://www.dephut. go.id/indexphp? =id /node/54(diakses tanggal 12 Januari 2011).

Markham, K.R., 1988, Cara Mengidentifikasi Flavonoid, diterjemahkan oleh Kosasih Padmawinata, 15, Penerbit ITB, Bandung.

Patel,T. and N. Shrivastava. 2007. Clerodendrum and Heathcare. Medicinal and Aromatic Plant Science and Biotechnology. 1: 142150.
Silverstein, R.M., Webster, F.X dan Kiemle, D.J. 2005. Spectrometric Identification of Organic Compounds, Seventh edition. United states of Amerika: John Wiley \& Son. Ltd

Umthong, S., Phuwapraisirisan, P., Puthong, S., and Chanchao, C., 2011, In Vitro Antiproliferrative on Human Cancer Cell Lines, BMC Complementary and Alterbative Medicine.

Wiart, C. 2002. Medicinal Plants of southeast Asia. Prentice Hall. Malaysia.

Yazid, E., 2005, Kimia Fisika Untuk Paramedis, Andi Yogyakarta, Yogyakarta. 